\title{
TR62 (Adana-Mersin) Bölgesinde Alternatif Yakıtlı Otomobil Satın Alma İstekliliğinin İncelenmesi
}

\author{
Seda Şengül ${ }^{1 *}$, Sezin Pusa ${ }^{2}$ \\ ${ }^{1}$ Çukurova Üniversitesi, İ̈BF, Ekonometri Bölümü, Adana, Türkiye (ORCID: 0000-0002-5648-3270) \\ ${ }^{2}$ Çukurova Üniversitesi, Sosyal Bilimler Enstitüsü, Adana, Türkiye (ORCID: 0000-0001-5304-4697)
}

(İlk Geliş Tarihi 23 Eylül 2019 ve Kabul Tarihi 22 Ekim 2019)

(DOI: 10.31590/ejosat.623492)

\begin{abstract}
ATIF/REFERENCE: Şengül, S., \& Pusa, S. (2019). TR62 (Adana-Mersin) Bölgesinde Alternatif Yakıtlı Otomobil Satın Alma
\end{abstract} İstekliliğinin İncelenmesi. Avrupa Bilim ve Teknoloji Dergisi, (17), 297-305.

\begin{abstract}
$\ddot{\mathbf{O} z}$
Çevre sorunlarının ve iklim değişikliğinin artması ile tüm dünyada olduğu gibi Türkiye'de de alternatif yakıtlı araçların kullanımı artmıştır. Elektrik ve hibrit otomobil kullanımının yaygınlaşması ile uluslararası literatürde bu konuyla ilgili çalışmalarda da önemli artışlar olmuştur. Türkiye genelinde alternatif yakıtlı otomobillerle ilgili ekonometrik çalışmaya uygun yeterli verinin olmaması, zaman ve maliyet gibi kısıtlardan dolayı veri toplamanın da zor olması nedeniyle, çalışmanın kapsamı, TR 62 Bölgesi illeri olan Adana ve Mersin'in kent merkezleriyle sınırlandırılmıştır. Çalışmanın verileri Adana-Mersin Bölgesi’nde ikamet eden bireylere yapılan anketlerden elde edilmiştir. Analiz yapılan anket sayıs1 563'tür. Bu çalışmada; yaş, cinsiyet, eğitim ve gelir gibi değişkenlerinin, alternatif yakıtlı otomobillerin yakıt kullanımının azalması, karbondioksit salınımının azalması, alternatif yakıtlı araçların satın alınmasını sağlaması için devlet teşviki verilmesi gibi çevreye duyarlılığı ölçmeye yönelik değişkenlerin, bireylerin alternatif yakıtlı otomobil tercih etme olasılıklarını nasıl etkilediğini belirlemek amaçlanmıştır. Çalışmanın bağımlı değişkeni birey alternatif yakıtlı otomobil satın alma istekliliğine sahipse 1, birey alternatif yakıtlı otomobil satın alma istekliliğine sahip değilse 0 değerini almaktadır. Bağımlı değişken iki değerli olduğundan çalışmanın modeli olarak logit model seçilmiştir. Logit modeli en çok olabilirlik tahmincisiyle tahmin edilmiştir. Çalışmada alternatif yakıtlı araç satın alma istekliliğinin en önemli belirleyicilerinin gelir, eğitim ve yakıt maliyetinin azalması olduğu saptanmıştır. Bireylerin gelirlerinde artış olması ve bireyin öğrenim düzeyinin üniversite olması alternatif yakıtlı otomobil satın alma olasılığını artırmaktadır. Hanedeki birey sayısında artı̧ olması durumunda ise alternatif yakıtlı otomobil satın alma olasılığında düşüş olmaktadır. Adana-Mersin bölgesinde yaşayan bireylerin alternatif yakıtlı lüks araç tipine göre alternatif yakıtlı mini araç satın alma olasılıkları düşük iken, alternatif yakıtlı orta tip ve Suv tipi otomobil satın alma olasılıkları ise daha yüksektir.
\end{abstract}

Anahtar Kelimeler: Alternatif Yakıtlı Otomobil, Logit Model, Adana, Mersin

\begin{abstract}
The use of alternative fuel vehicles has increased all over the world due to the increase in environmental problems and climate change. Likewise, in Turkey also increased the use of alternative fuel vehicles with the widespread use of electricity and hybrid automobiles, there has been a significant increase in studies on this subject in the international literature. No studies on alternative fuel vehicles in Turkey called to the less. The reason for this is that the subject is new and there is not enough data ofeconometric studies on alternativefuel vehicles in Turkey. In general collecting data is very dificult because of constraints such as time and cost. For this reason, the extent of this study is limited to the urban centers of Adana and Mersin's province called TR-62 region. The data of the study were obtained from the questionnaires conducted to individuals living in TR62 region. The number of surveys was 563. In this study; It is aimed to determine how variables such as age, gender, education and income, decreasing fuel consumption of alternative fueled cars, decreasing carbon dioxide emission, and giving government incentives to purchase alternative fueled vehicles affect the possibilities of individuals to choose alternative fueled cars. The dependent variable of the study is 1 if the individual is willing to buy alternative fueled cars and 0 if the individual is not willing to buy alternative fueled cars. Since the dependent variable has two values, the logit model was chosen as the model of the study. The Logit model was estimated by the maximum likelihood. In the study, the most important determinants of willingness to buy alternative fuel vehicles were found to be the decrease in income, education and fuel costs. The increase in individuals' income and the level of education of the individual increases the likelihood of buying alternative fueled cars. In case of an increase in the number of individuals in the household, there is a decrease in the possibility of buying alternative fueled cars. Individuals living in
\end{abstract}

\footnotetext{
* Sorumlu Yazar: Çukurova Üniversitesi, İiBF, Ekonometri Bölümü, Adana, Türkiye, ORCID: 0000-0002-5648-3270, ssengul@cu.edu.tr
} 
the Adana-Mersin region are less likely to purchase alternative fueled mini-vehicles than the alternative fueled luxury vehicles, while the possibility of purchasing alternative fueled medium-type and SUVs is higher than alternative fueled luxury vehicles in TR 62 regions.

KeyWords: Alternative fuel vehicle, Logit Model, Adana, Mersin

\section{Giriş}

Dünya atmosferi çeşitli gazlardan oluşmaktadır. Güneşten gelen ışınlar (1sı1 1şınları, kısa dalgalı 1şınlar) atmosferi geçerek yeryüzünü 1sıtmaktadır. Atmosferdeki gazlar yeryüzündeki 1sının bir kısmını tutmaktadır ve yeryüzünün 1sı kaybına engel olmaktadır (karbondioksit $\left(\mathrm{CO}_{2}\right)$ havada en çok 1sı tutma özelliği olan gazdır). Son yıllarda atmosferdeki $\mathrm{CO}_{2}$ miktarı hava kirlenmesine bağlı olarak hızla artmaktadır. Metan, ozon ve kloroflorokarbon (CFC) gibi sera gazları çeşitli insan aktiviteleri ile atmosfere katılmaktadır. Bu gazların tamamının ısı tutma özelliği vardır. $\mathrm{CO}_{2}$ ve ısıyı tutan diğer gazların miktarındaki artış, atmosferdeki ısının yükselmesine sebep olmaktadır. Bu da küresel ısınma olarak ifade edilmektedir. Bu durumun, buzulların erimesi ve okyanusların yükselmesi gibi ciddi sonuçlar doğuracak iklim değişmelerine yol açmasından endişe edilmektedir. Atmosferde, ozonun $\left(\mathrm{O}_{3}\right)$ yoğunluğunu azaltan kloroflorokarbon (CFC) gazları ve karbondioksit $\left(\mathrm{CO}_{2}\right)$, metan $\left(\mathrm{CH}_{4}\right)$, diazot monoksit $\left(\mathrm{N}_{2} \mathrm{O}\right)$ gibi sera gazlarının miktarlarında önemli ölçüde artışlar olmuştur. Bu artışlardan dolayı atmosferde kuvvetlenen sera işlemi, beraberinde günümüzdeki küresel ısınma ve küresel iklim değişimi problemlerini ortaya çıkarmaktadır. İklim değişikliğinin dünya genelindekiolumsuz etkilerinin oldukça yüksek olacağı öngörülmektedir. Bu olumsuzluklar, hazırlanan çeşitli senaryolara göre Türkiye'nin de içinde bulunduğu enlemlerde, sıcaklıklardaki artışların; yağış rejiminde değişmeler, deniz suyu seviyesinde yükselmeler ve toprak su içeriğinde önemli azalmalar şeklinde olacağ 1 tahmin edilmektedir (Şengül, 2013).

Türkiye, 1999 yılına ilişkin temel $\mathrm{CO}_{2}$ göstergeleri açısından dünya ülkeleri arasında toplam $\mathrm{CO}_{2}$ emisyonunda 23 'üncü, kişi başına $\mathrm{CO}_{2}$ emisyonu açısından 75'inci, $\mathrm{CO}_{2}$ emisyonunun gayri safi yurtiçi hasılaya (GSYİH) oranında 60'ıncı sırada yer almaktadır. Türkiye 1998 yılında iklim değişikliği raporu hazırlamış, linyit ve taşkömüründen doğal gaza geçerek $\mathrm{CO}_{2}$ emisyonlarının artış hızını azaltmıştır. Ayrıca, 1997 Kyoto Protokolü, İklim Değişikliği hakkında ve 1998 Aarhus Sözleşmesi, çevresel bilgiye erişim hakkındaki konuların dışında çevre konusundaki önemli tüm sözleşme ve protokolleri imzalamış ve bu sözleşmelerin TBMM'de onaylamasını sağlamıştır. Bu kapsamda, on sekiz civarında uluslararası sözleşme onaylanmıştır. Türkiye’nin bu duyarlığı OECD'nin Çevresel Başarı Raporu'na yansımıştır (Özmen, 2009, s.45).

İklim değişikliği, çevreye duyarlılık ve enerji güvenliği ile ilgili endişeler çevre dostu teknolojilerin gelişmesine neden olmuş, daha yeşil ve sorunsuz bir çevre ayrıca çevreyi olumsuz etkileyecek gazlardan uzak durmak için birçok alanda çalışmalar yapılmıştır. Bu nedenle içten yanmalı motorlu araçlara kıyasla sera gazını, karbondioksit gazını ve emisyonlarını azaltan elektrik, hibrit ve pil gibi alternatif yakıt kullanan otomobillere ilgi artmış ve bu otomobiller pazar piyasasına girmeye başlamıştır. ABD'de, Avrupa ülkelerinde ve Japonya'da alternatif (elektrik, hibrit) yakıtlı otomobillerin tüketimini özendirmek için alıcı ve satıcılara vergi indirimi vb. destekler sağlamaktadır.ABD'de 2009 yılı Amerikan Geri Kazanma ve Yeniden Yatırım Yasası, elektrikli araçlar için 2500 ila 7500 ABD doları arasında vergi kredisi sağlayan, tüketici vergisi teşviklerini uzatmıştır. İngiltere'de elektrikli otomobil için 2011 'de satın alanlar 2000 ila 5000 libre arasında değişen bir indirime hak kazanabilmişlerdir (Ito, Takeuchi ve Managi, 2012). Türkiye'de de elektrik ve hibrit yakıtlı otomobillerin alımını teşvik etmek amacıyla özel taşıt vergisi indirimi adı altında destek sağlanmıştır. Elektrikli otomobilde, aracın kilovat cinsinden motor gücüne bağlı olarak farklı oranlarda vergiler uygulanmıştır. Örneğin, ÖTV'si \%45 olan 1600 cc altındaki normal bir otomobilin, yine aynı güce denk gelen elektrikli bir otomobille karşılaştırıldığında ÖTV'si \%3 oranındadır. 85-120 kilovat arası \%7, 120 kilovat üstü için de \%15 şeklinde üç ayrı vergilendirme dilimi oluşturulmuştur. Dolayısıyla bugün, 2000 cc üstü bir otomobile yaklaşık \%145 ÖTV ödenirken aynı güçteki elektrikli otomobilde bu oran sadece \%15'tir (TEHAD, 2016). Türkiye'de son yıllarda özel vergi indirimleriyle elektrikli otomobillerin alımının teşvik edilmesine karşın, bu teşvik ABD ve Avrupa Birliği ülkeleriyle kıyaslandığında son derece düşüktür. Bu tür otomobiller geleneksel otomobillere göre daha farklı özelliklere sahip olduklarından fiyatları daha yüksektir ve bu otomobilleri satın alabilecek müşterilerin özelliklerinin de geleneksel otomobilleri satın alan müşterilerin özelliklerinden farklı olması beklenmektedir. Uluslararası yazında konuyla ilgili çok çalışma yapılmışken (Dreyfus, 1995; Musardo, 2003; Blomquist, 2004; Andriosopoulos, 2018), Türkiye'de alternatif yakıtlı otomobil piyasası çok yeni olduğundan konuyla ilgili çalışmalar çok azdır (Aydemir, 2014 ve Kerem, 2014). Bu çalışmada cinsiyet, eğitim, meslek ve gelir gibi değişkenlerin yanı sıra yakıt kullanımındaki, karbondioksit salınımındaki azalma, devlet teşviki gibi çevreye duyarlılığı ölçmeye yönelik değişkenlerin bireylerin alternatif yakıtlı araç tercih etme olasılıklarını belirlemek amaçlanmıştır. Türkiye genelinde veri toplama zor olduğundan çalışmanın kapsamı TR62 (Adana-Mersin) Bölgesi olarak sınırlandırılmıştır.

Bu çalışmanın önemi Adana-Mersin Bölgesinde, tüketicilerin alternatif yakıtlı otomobil satın alma olasılı̆̆ını belirleyerek, özelde Adana-Mersin Bölgesinde, genelde Türkiye'de alternatif yakıtlı otomobillerin potansiyel talebini artırmaya yönelik politikalarının oluşturulmasına katkı sağlayacak olmasından kaynaklanmaktadır.

Bu çalışmanın ikinci bölümde çalışmanın anketi, anketten elde edilen verilerin özelliği ve çalışmada uygulanan ekonometrik model tanıtılmıştır. Üçüncü bölümde modelde kullanılan değişkenler, değişkenlerin özellikleri ve araştırma bulguları sunulmuştur. Son bölüm sonuç bölümü olup araştırma bulgularından elde edilen çıkarımlar verilmiş, alternatif yakıtlı araç kullanımını artırmak için politika önerilerinde bulunulmuştur.

\section{Materyal ve Metot}




\section{1. Çalışmanın Anketi}

Türkiye genelinde elektrik ve hibrit yakıtlı araç kullanımıyla ilgili sınırlı veri olması nedeniyle çalışmanın verileri anket yoluyla toplanmıştır. Nüfus, coğrafya, bölgesel kalkınma planları, temel istatistiki göstergeler, illerin sosyoekonomik gelişmişlik sıralaması kriterleri göz önüne alınarak Türkiye'de 12 tane Düzey 1, 26 tane Düzey 2 ve 81 tane Düzey 3 bölgesi tanımlanmıştır. Düzey 2 sınıfları, TR10, TR21, TR22, TR31, TR32, TR33, TR41, TR42, TR51, TR52, TR61, TR62, TR63, TR71, TR72, TR81, TR82, TR83, TR90, TRA1, TRA2, TRB1, TRB2, TRC1, TRC2, TRC3'tür. Aralık 2018-Şubat2019 tarihleri arasında rassal seçilen 600 bireyden toplanmıştır. Ancak eksik veri, hatalı veri vb. nedenlerden dolayı analizler 563 veri ile yapılmışıtır. Bu ankette toplam geliri, toplam tüketim harcaması, hanehalkı büyüklügü̈, hanede yaşayan bireylerin cinsiyeti, yaşı, çalışma alanı, mesleği, otomobil sahipliği, otomobilin tipi, yakıt için yapılan harcama, sahip olunan otomobilin yakıt tipi, alternatif yakıtlı otomobil satın alma istekliliği, alternatif yakıtlı otomobil satın almayı isteme nedenleri vb. değişkenler yer almaktadır.

\subsection{Anketten Sağlanan Verilerinin Özelliği}

Adana-Mersin illerinde alternatif yakıtlı araç kullanımıyla ilgili anket yapılan anketten sağlanan değişkenlerin özet istatistikleri tablolar halinde sunulmuştur. Tablo 1'de Adana-Mersin illerinde alternatif yakıtlı araç kullanımıyla ilgili anket yapılan bireylerin sosyodemografik özelliklerinin frekans tablosu verilmiştir.

Tablo 1. Adana-Mersin Bölgesinde Anket Yapılan Bireylerin Sosyo-Demografik Özellikleri

\begin{tabular}{|c|c|c|}
\hline Değişkenler & Tanım & Frekans (\%) \\
\hline \multirow{2}{*}{ Cinsiyet } & Kadın & 69.98 \\
\hline & Erkek & 30.02 \\
\hline \multirow{5}{*}{ Ĕ̈itim } & Okur-yazar değil, diplomasız okur-yazar & 0.18 \\
\hline & İlkokul, ilkögrretim, ortaokul, orta dengi meslek okulu & 7.99 \\
\hline & Lise, lise dengi meslek & 17.94 \\
\hline & İki ylllk yüksekokul, dört yllllk yüksekokul, fakülte, & \\
\hline & master, doktora & 73.89 \\
\hline \multirow[t]{6}{*}{ Çalışma Alant } & $\ddot{U}$ cretli & 1.24 \\
\hline & Maaşlı & 61.28 \\
\hline & Yevmiyeli & 0.71 \\
\hline & Kendi Hesabına & 4.44 \\
\hline & Işveren & 12.08 \\
\hline & $\ddot{U c r e t s i z ~ a i l e ~ i s ̧ c ̧ i s i ~}$ & 20.25 \\
\hline \multirow[t]{11}{*}{ Meslek } & Emekli & 7.28 \\
\hline & Meтur & 20.96 \\
\hline & $\dot{I} s ̧ c ̧ i$ & 8.88 \\
\hline & Esnaf & 9.24 \\
\hline & Ev hanımı & 6.22 \\
\hline & $\dot{I}_{S ̧}$ adamı & 4.80 \\
\hline & Kariyer Meslek (Avukat, Doktor, Mühendis, Yönetici), & 25.58 \\
\hline & Ögrenci & 11.72 \\
\hline & $\dot{I}_{\text {Şsiz }}$ & 2.84 \\
\hline & Diğer & 2.49 \\
\hline & Ortalama & Std. Sapma \\
\hline Yaş & 37.696 & 11.874 \\
\hline
\end{tabular}

Tablo 1 incelendiğinde ankete katılanların \%69.98'inin kadın, \%30.02'sinin erkek olduğu görülmektedir. Bireylerin eğitim durumlarına bakıldığında ise \%73.89'uyüksek öğrenim düzeyine, \%17.94'ü lise, lise dengi meslek okul öğrenim düzeyine, \%7.99'u ise ilkokul, ortaokul öğrenim düzeyine sahiptir.

Bireylerin \%61.28'i maaşlı, \%20.25'i ücretsiz aile işçisi, \%12.08 işveren, \%4.44'ü kendi hesabına, \%1.24'ü ücretli, \%0.71'i yevmiyeli olarak çalışmaktadır. TR 62 bölgesinde bireylerin \%25.58'si kariyer meslek sahibi, \%20.96's1 memur, \%11.72 öğrenci, \%9.24'ü esnaf, \%8.88'i işçi, \%7.28'i emekli, \%6.22'si ev hanımı, \%4.80'i iş adamı, \%2.84'ü işsizdir ve yaş ortalamaları yaklaşık olarak 37'dir.

Tablo 2'de Adana-Mersin Bölgesinde anket yapılan bireylerin otomobil ile ilgili frekans tablosu sunulmuştur. 
Tablo 2. Adana-Mersin Bölgesinde Anket Yapılan Bireylerin Otomobilleri ile ilgili Frekans Tablosu

\begin{tabular}{|c|c|c|}
\hline Değişkenler & Seçenekler & Frekans (\%) \\
\hline \multirow{2}{*}{ Otomobil } & Otomobili olanlar & 70.87 \\
\hline & Otomobili olmayanlar & 29.13 \\
\hline \multirow{4}{*}{ Otomobil Tipi } & Mini/küçük araçlar & 12.78 \\
\hline & Orta/geniş araçlar & 72.43 \\
\hline & SUV/Crossover araçlar & 8.52 \\
\hline & Üst sınıf/lüks/spor araçlar & 6.27 \\
\hline \multirow{2}{*}{ Yakıt Tipi } & Benzin/LPG & 40.60 \\
\hline & Dizel & 59.40 \\
\hline \multirow{3}{*}{ Araba Alma Nedeni } & Eskisinin yerine & 54.39 \\
\hline & Ek olarak bir araba daha & 17.54 \\
\hline & Ilk $a r a b a$ & 28.07 \\
\hline \multirow[t]{5}{*}{ Sürüş Aralı̆̆ı } & $<=50 \mathrm{~km}$ & 60.65 \\
\hline & $51-100 \mathrm{~km}$ arast & 31.83 \\
\hline & $101-150 \mathrm{~km}$ arast & 6.77 \\
\hline & $151-200 \mathrm{~km}$ arast & 0 \\
\hline & $>=201 \mathrm{~km}$ & 0.75 \\
\hline
\end{tabular}

TR 62 Bölgesinde bireylerin \%70.87'sinin otomobilinin olduğu, \%29.13’ünün otomobilinin olmadığı belirlenmiştir. Otomobili olanların \%12.78'inin otomobili mini/küçük otomobil grubunda, \%72.43'ünün otomobili ise orta/geniş otomobil grubunda yer almaktadır. Otomobil sahibi olan bireylerin \%59.40'1nın otomobili dizel yakıtlı iken, \%40.60'ının otomobili benzinli ya da LPG yakıtlıdır. Bireylerin en son satın aldıkları otomobili satın alma nedenleri incelendiğinde bireylerin \%54.59'u eski otomobillerini değiştirdiklerini, \%28.07'si kullandıkları otomobilin ilk otomobilleri olduğunu, \%17.54'ü ise bir otomobillerinin olduğunu ek bir otomobil daha satın aldıklarını ifade etmişlerdir. Bireylerin günlük otomobil sürüş aralığına bakıldığında ise günlük sürüş aralığının bireylerin \%60.65'i için $50 \mathrm{~km}$ ya da daha az, \%31.83'ü için 51-100 km arası, \%6.77'si için günlük 101-151 km arasında olduğu görülmektedir.

Tablo 3 'te hane başına düşen ortalama otomobil sayısının 0.95 , otomobil alış fiyatının ortalama 57602 TL ve aylık ortalama yakıt harcamasının ise ortalama 308 TL olduğu görülmektedir.

Tablo 3. Hanedeki Otomobiller Sayısı, Alış Fiyatı, Aylık Yakıt harcaması için Özet İstatistikler

\begin{tabular}{|lcc|}
\hline Toplam & Ortalama (TL) & Std. Sapma (TL) \\
\hline Hanedeki toplam otomobil sayısı & 0.95 & 0.83 \\
\hline Araç Alış fiyatı & 57602.66 & 85945.95 \\
\hline Aylık yakıt harcaması & & 334.95
\end{tabular}

Tablo 4 incelendiğinde otomobil satın almayı planlayan bireylerin oranının \%45.12 olduğu belirlenmiştir. Bireylerin \%26.38’i bir yıl içinde, \%34.65'i iki yıl içinde, \%38.97'si dört yıl içinde otomobil satın almak istemektedir. Otomobil satın almayı planlayanların $\% 22.75$ 'i mini-küçük otomobil satın almayı, \%14.90’ı üst sınıf otomobil satın almayı planlamaktadır. Tablo 4 incelendiğinde otomobil satın almayı planlayanların \%60.39'u elektrikli ve hibrit gibi alternatif yakıtlı otomobil satın almayı planlamakta olup, alternatif yakıtlı otomobil satın almak isteyenlerin $\% 12.75$ 'i mini-küçük otomobil satın almak isterken \%72.12'si orta-geniş tip otomobil satın almak istemektedirler. 
Tablo 4. Otomobil Satın Almayı Planlayanlarla İlgili Özet İstatistikler

\begin{tabular}{|c|c|c|}
\hline Tanım & Cevap & Frekans (\%) \\
\hline \multirow[b]{2}{*}{ Otomobil satın almayı planliyor musunuz? } & Evet & 45.12 \\
\hline & Hayır & 54.88 \\
\hline Bir yıl içinde otomobil satın almayı planlayanlar & & 26.38 \\
\hline İki yıl içinde otomobil satın almayı planlayanlar & & 34.65 \\
\hline Dört yll içinde otomobil satın almayı planlayanlar & & 38.97 \\
\hline \multirow{4}{*}{ Hangi tip otomobil satın almayı planlyyorsunuz? } & Mini/küçük araçlar & 22.75 \\
\hline & Orta/geniş araçlar & 58.43 \\
\hline & SUV/Crossover araçlar & 3.92 \\
\hline & Üst sınıf/lüks/spor araçlar & 14.90 \\
\hline & Evet & 60.39 \\
\hline $\begin{array}{l}\text { Satın almayı planladı̆̆ını otomobilin alternatif } \\
\text { yakttl (hibrit-elektrik) olmasını tercih edermisiniz? }\end{array}$ & Hayır & 39.61 \\
\hline \multirow{4}{*}{$\begin{array}{l}\text { Satın almayı planladı̆̆ınız alternatif yakıtl (hibrit- } \\
\text { elektrik) otomobilin otomobiltipinin ne olmasını } \\
\text { tercih edersiniz? }\end{array}$} & Mini/küçük araçlar & 12.75 \\
\hline & Orta/geniş araçlar & 72.12 \\
\hline & SUV/Crossover araçlar & 12.21 \\
\hline & Üst sınıf/lüks/spor araçlar & 2.94 \\
\hline
\end{tabular}

Tablo 5'te bireylerin alternatif yakıtlı otomobili tercih etme nedenlerini belirlemek üzere 5'li likert ölçeğine göre (1-hiç katılmıorum, 5-her zaman katıliyorum) sorulan "alternatif yakıtlı otomobiller çevre dostu ürünlerdir" ve "alternatif yakıtlı otomobillerin $\mathrm{CO}_{2}$ emisyon salınımı daha azdır" ifadelerine verilen cevapların ortalamaları yaklaşık 4.5 olduğundan bireylerin bu ifadelere her zaman katıldıklarını göstermektedir.

Tablo 5. Alternatif Yakıtlı Otomobiller İçin Çevresel Etmenlerle İlgili Özet İstatistikler

\begin{tabular}{|lcc|}
\hline & Ortalama & Std. Sapma \\
\hline Alternatifyakttlı otomobiller çevre dostu ürünlerdir. & 4.558 & 0.559 \\
\hline $\begin{array}{l}\text { Alternatif yakıtl otomobillerin } \mathrm{CO}_{2} \text { emisyon salınımı daha } \\
\text { azdır. }\end{array}$ & 4.632 & 0.640 \\
\hline
\end{tabular}

\subsection{Logit Modeli}

Adana-Mersin bölgesinde yaş, cinsiyet, eğitim ve gelir gibi değişkenlerin yanı sıra yakıt kullanımındaki, karbondioksit salınımındaki azalma, devlet teşviki gibi çevreye duyarlılığı ölçmeye yönelik değişkenlerin bireylerin alternatif yakıtlı araç tercih etme olasılıklarını nasıl etkilediği Logit modeliyle belirlenmiştir.

Logit modelleri, logit regresyona tabi olan ve özellikle ikili bağımlı değişkenler için tasarlanmış doğrusal olmayan fakat uygun dönüşümler ile doğrusallaştırılabilen bir regresyon modelidir. Bireyin alternatif yakıtlı otomobil satın alma olasılığı yaş, eğitim ve aile geliri gibi açılayıcı değişkenlere dayanan gözlemlenemeyen bir fayda endeksi $I_{i}^{*}$ ’a bağlı olduğu varsayılsın. Bu endeks;

$$
I_{i}^{*}=B X+u_{i}
$$

şeklinde ifade edilir. Burada $\mathrm{i}=\mathrm{i}$ 'nci birey ve $\mathrm{u}=$ hata terimidir. Gözlemlenemeyen fayda endeks alternatif yakttl otomobil almayı planlama ya da almamayı planlama kararıyla aşağıdaki şekilde ilişkilendirilir.

$I_{i}^{*} \geq 0$ ise $Y_{i}=1$ (kişi alternatif yakıtlı otomobil satın almayı planlıyorsa.)

$I_{i}^{*} \leq 0$ ise $Y_{i}=0$ (kişi alternatif yakıtlı otomobil satın almayı planlamıyorsa.)

Yani bir kişinin I fayda endeksi I* eşik değerinin üzerindeyse birey alternatif yakıtlı otomobil satın almayı planlıyor, fakat I'den küçükse alternatif yakıtlı otomobil satın almamayı planlıyorsa şeklinde ifade edilir.

$\mathrm{Bu}$ tercihin işlemsel hale getirilmesi için bir tercihte bulunmanın olasılığı cinsinden düşünülebilir.

$$
\begin{aligned}
\operatorname{Pr}\left(Y_{i}=1\right) & =\left(\operatorname{Pr} I_{i}^{*} \geq 0\right) \\
& =\operatorname{Pr}\left[\left(B X+u_{i}\right) \geq 0\right]
\end{aligned}
$$


$=\operatorname{Pr}\left(u_{i} \geq-\mathrm{BX}\right)$

Artık bu olasılık $Y_{i}^{\prime}$ nin (olasılık) dağılımına, bu da $u_{i}$ hata teriminin olasılık dağılımına bağlıdır. Eğer olasılık dağılımı (sıfır) ortalama değeri etrafında simetrikse, (2.3) eşitliği

$\operatorname{Pr}\left(u_{i} \geq-\mathrm{BX}\right)=\operatorname{Pr}\left(u_{i} \leq \mathrm{BX}\right)$

şeklinde yazılabilir. Dolayısıyla;

$P_{i}=\operatorname{Pr}\left(Y_{i}=1\right)=\operatorname{Pr}\left(u_{i} \leq \mathrm{BX}\right)$

Açıkça görülüyor ki, u' 'ninbirikimli dağılım fonksiyonu ait olasılık dağılımının Lojistik olasılık dağılımı olduğunu varsaydığından modelde logit model olmaktadır (Eşitlik 2.4).

$$
P_{i}=\frac{1}{1+e^{-Z i}}
$$

$$
Z_{i}=B X \mathrm{i}+u_{i}
$$

Fonksiyonda da görüldüğü gibi Pi hem bağımsız değişkene hem de parametrelere göre doğrusal değildir (Gujarati, 2006). Bir olayın gerçekleşme olasılığı ile gerçekleşmeme olasılığı birbirine oranlandığında elde edilen oran, bahis oranının (fark oranı, oddsratio) logaritması (Eşitlik 2.5). $L_{i}$ logit (bahis oranı) olarak bilinir. Logit modeli en çok olabilirlik tahmincisiyle tahmin edilir.

$$
L_{i}=\ln \left(\frac{P_{i}}{1-P_{i}}\right)=Z_{i}=B X+u_{i}
$$

Logit modelde marjinal etkilerin yorumu; diğer değişkenler sabit tutulduğunda ilgili açıklayıcı değişken bir yıl arttı̆̆ında alternatif yakıtlı otomobil satın alma olasılığını yaklaşık olarak marjinal etki değeri kadar (pozitif veya negatif işaretli değere göre) arttırır veya azaltır şeklinde yapılır (Gujarati, 2016, s.239).

Logit modellerinde, katsayı yorumu için marjinal etkilerden yararlanılmaktadır. Marjinal etki Eşitlik 2.6 şeklinde hesaplanmaktadır.

Marjinal etki=BiPi $(1-P i)$.

Buna göre, olasıllğın bağımsız değişkene göre değişme oranının sadece Bi'ye değil, aynı zamanda değişimin ölçüldüğü olasıllı̆ın düzeyine de bağlı olduğu gösterir. Bu da, bağımsız değişkenlerdeki değişmenin, herhangi bir tercihin seçilme olasılığı üzerine en büyük etkisinin, dağılımın orta noktasında meydana geldiğini belirtmektedir.

\section{Araştırma Sonuçları ve Tartışma}

\subsection{Modelde Kullanılan Değișkenler ve Tanımlayıcı İstatistikleri}

Tablo 6'da Adana-Mersin Bölgesinde elektrikli vehibrit otomobil satın alma olasıllğı belirlemede kullanılan değişkenlerin tanımları ve tanımlayıcı istatistikleri verilmiştir.

Adana-Mersin Bölgesi kent merkezinde ikamet eden bireylerin alternatif yakıtlı otomobil satın alma olasılıklarını belirlemede kullanılan Logit modelinin bağımlı değişkeni birey alternatif yakıtlı otomobil satın almak istiyorsa 1, satın almak istemiyorsa 0 değerini aldığı nitel bir değişkendir. Sahip olunan otomobil tipinin mini, orta büyüklükte, SUV ve üst sinıfta olması modele açıklayıcı değişken olarak eklenmiştir. Alternatif yakıtlı otomobiller diğer yakıtlı otomobillere göre daha pahalıdır. Otomobil tiplerine göre otomobil fiyatlarının farklılık göstermesi nedeniyle bu değişkenler modele dahil edilmiştir. Üst sınıf otomobil kategorisi referans değişken olarak alınmıştır. Alternatif yakıtlı araçlar çevreye duyarlı araçlar olduklarından bireylerin hangi durumda bu araçları satın alacaklarını belirlemek için 3 farklı senaryo oluşturulmuş ve bu senaryoları temsil eden değişkenler kukla değişken olarak modele dahil edilmiştir. $\mathrm{Bu}$ senaryolardan; alternatif yakıtlı otomobilin fiyatının $\% 25$ artması, yakıt maliyetinin $\% 50$ azalması durumunda satın alınırsa 1 , satın alınmazsa 0 değerini alan kukla değişken, alternatif yakıtlı otomobilin fiyatının $\% 25$ artması, $\mathrm{CO}_{2}$ emisyon salınımının $\% 50$ azalması durumunda satın alınırsa 1, satın alınmazsa 0 değerini alan kukla değişken ile alternatif yakıtlı otomobilin fiyatının \%25 artması, yakıt maliyetinin ve $\mathrm{CO}_{2}$ emisyon salınımının \%50 azalması durumunda satın alınırsa 1, satın alınmazsa 0 değerini alan kukla değişkenler oluşturulmuştur. Ayrıca alternatif yakıtlı otomobillerin satın alınması için devlet teşvikinin verilmesi durumunda 1, verilmemesi durumunda 0 değerini alan kukla değişkende modele eklenmiştir. Bireyin yaşı, çalıştığ 1 işin kariyerli bir iş olması, öğrenim düzeyi ve hanesindeki birey sayısı da modele açıklayıcı değişken olarak dahil edilmiştir. Ayrıca hanenin toplam harcamasının logaritması da toplam geliri temsilen modele eklenmiştir. 


\begin{tabular}{|c|c|}
\hline Değişkenler & Tanımları \\
\hline Alteroto & Alternatif yakıtlı otomobil satın almak isteniyorsa 1 , değilse 0 (logit modelin bağımlı değişkeni) \\
\hline Miniarac & Otomobil tipi mini ise 1 değilse 0 \\
\hline Ortaarac & Otomobil tipi orta ise 1 değilse 0 \\
\hline Suv & Otomobil tipi SUV ise 1 değilse 0 \\
\hline Üst sinif & Otomobil tipi üst sınıf ise 1 değilse 0 (referans) \\
\hline Alter2550 & Alternatif yakıt tüketen aracın satış fiyatı $\% 25$ artarsa, yakıt maliyeti $\% 50$ azalırsa 1 , değilse 0 \\
\hline Alter $25 \mathrm{CO}_{2}$ & Alternatif yakıt tüketen aracın satış fiyatı $\% 25$ artarsa, $\mathrm{CO}_{2} \% 50$ azalırsa 1 , değilse 0 \\
\hline Alter 255050 & $\begin{array}{c}\text { Alternatif yakıt tüketen aracın satış fiyatı } \% 25 \text { artarsa, yakıt maliyeti } \% 50 \text { azalırsa, CO2 \%50 azalırsa } \\
1 \text {, değilse } 0\end{array}$ \\
\hline Devtes & Devlet teşvik verirse 1 , değilse 0 \\
\hline Illkokul & Birey bir okul bitirmedi, ilkokul-ilköğretim, ortaokul mezunu ise 1 , değilse 0 (referans) \\
\hline Lise & Birey lise mezunu ise 1 değilse 0 \\
\hline Üniversite & Birey üniversite mezunu ise 1 değilse 0 \\
\hline Yas & Bireyin yaş1 \\
\hline Call & Bireyin işi kariyer meslek (avukat, doktor vb) \\
\hline Ltophar & Toplam harcamanın logaritması \\
\hline Hanebüy & Hane halkı büyüklüğü \\
\hline
\end{tabular}

Çalışmada kullanılan değişkenlerin tanımlayıcı istatistikleri Tablo 7'de sunulmuştur. Tablo 7'ye göre alternatif yakıtlı otomobilin fiyatının $\% 25$ artması, yakıt maliyetinin $\% 50$ azalması durumunda alternatif yakıtlı otomobil satın alacak bireylerin oranı $\% 56$ iken, alternatif yakıtlı otomobilin fiyatının $\% 25$ artması, $\mathrm{CO}_{2}$ emisyon salınımının $\% 50$ azalması durumunda bireylerin $\% 33$ ü alternatif yakıtlı otomobil satın almak istemektedir. Alternatif yakıtlı otomobilin fiyatıın $\% 25$ artması, yakıt maliyetinin $\% 50$ azalması ve $\mathrm{CO}_{2}$ emisyon salınımının $\% 50$ azalması durumunda ise bireylerin $\% 42$ 'si alternatif yakıtlı otomobil satın almak istemektedir. Devlet teşvikinin verilmesi durumunda alternatif otomobil satın almak isteyen vireylerin oranı ise $\% 52$ 'dir.

Tablo 7. Tanımlayıcı İstatistikler

\begin{tabular}{|lcc|}
\hline Değişkenler & Ortalama & Standart sapma \\
\hline Alteroto & 0.60 & 0.48 \\
Alternatif oto yok & 0.40 & 0.54 \\
Miniarac & 0.13 & 0.28 \\
Ortaarac & 0.72 & 0.49 \\
Suv & 0.09 & 0.23 \\
Üst sinff & 0.06 & 0.20 \\
Alter2550 & 0.56 & 0.49 \\
Alter25CO & 0.33 & 0.47 \\
Alter255050 & 0.42 & 0.39 \\
Devtes & 0.52 & 0.21 \\
\hline Ilkokul & 0.09 & 0.32 \\
Lise & 0.18 & 0.38 \\
Üniversite & 0.73 & 0.43 \\
\hline Yas & 37.73 & 11.79 \\
Call & 0.25 & 0.43 \\
Ltophar & 0.78 & 0.41 \\
Hanebüy & 3.00 & 1.05 \\
\hline Örneklem büyüklüğ̈ & 563 & \\
\hline
\end{tabular}


Adana-Mersin Bölgesi’nde elektrik vehibrit otomobil satın alma olasılı̆̆ Logit modelinin en çok olabilirlik yöntemiyle tahmin edilmesi ile belirlenmiştir. Tablo 8'de Logit modelinin parametre tahminleri verilmiştir.

Tablo 8 incelendiğinde modelde yer alan açıklayıcı değişkenlerin parametrelerinin (lise mezunu olmak ve bireyin yaşı hariç) büyük bölümü istatistiksel olarak anlamlı bulunmuştur.

Tablo 8. Logit Modelin Parametre Tahminleri

\begin{tabular}{|lccc|}
\hline Değişkenler & Katsayı & t istatistiği & Marjinal etki \\
\hline Sabit & -0.87 & $-1.77^{*}$ & \\
Miniarac & -0.98 & $-2.76^{* *}$ & -0.22 \\
Ortaarac & 1.55 & $2.76^{* *}$ & 0.28 \\
Suv & 1.33 & $6.51^{* *}$ & 0.25 \\
Alter2550 & 0.44 & $2.81^{* *}$ & 0.27 \\
Alter25CO & -0.08 & $-7.17^{* *}$ & -0.034 \\
Alter255050 & 0.39 & $2.11^{* *}$ & 0.15 \\
Devtes & 0.14 & $2.55^{* *}$ & 0.03 \\
Lise & -0.020 & -0.54 & -0.04 \\
Üniversite & 0.129 & $2.25^{* *}$ & 0.03 \\
Yas & 0.011 & 1.31 & 0.003 \\
Cal1 & 0.65 & $2.96^{* *}$ & 0.16 \\
Hanebuy & -0.23 & $-2.29^{* *}$ & -0.03 \\
Ltophar & 0.13 & 0.036 \\
\hline Loglikelihood & -329.69 & \\
\hline LR(14) & 115.31 & \\
\hline Pseudo $\boldsymbol{R}^{2}$ & 0.148 & \\
*: \%5 önem anlamll1k düzeyi; **: \%10 önem anlamll11k düzeyi & \\
\end{tabular}

Tablo 8 incelendiğinde, mini araç sahip olmanın elektrikli ve hibrit otomobil satın alma isteği üzerindeki etkisi negatif iken orta büyüklükte araç ve SUV sahip olmanın alternatif yakıtlı araç satın alma isteği üzerindeki etkisi pozitiftir. Alternatif yakıtlı otomobillerin alış fiyatı $\% 25$ artmasının, yakıt maliyetinin $\% 50$ azalmasının bireylerin elektrikli ve hibrit otomobil satın alma istekliliği üzerindeki etkisinin pozitif olduğu belirlenmiştir. Alternatif yakıtlı otomobillerin araç alış fiyatının $\% 25$ artmasının, CO2 emisyon salınımının $\% 50$ azalmasının etkisi ise negatif bulunmuştur. Ancak hem yakıt maliyetinin hem de $\mathrm{CO} 2$ emisyon salınımın \%50 azalmasının etkisi pozitiftir. Devlet teşvikinin verilmesinin, bireyin üniversite öğrenim düzeyinde olmasının, toplam harcamadaki artışın alternatif yakıtlı otomobil satın alımı üzerindeki etkisi pozitif iken, hanedeki birey sayısındaki artışın etkisi negatiftir.

Marjinal etkiler incelendiğinde, mini araç kullanan bireylerin elektrikli ve hibrit otomobil satın alma olasılıklarının üst sınıf araç kullananlara göre 0.22 kadar daha düşük olduğu belirlenmiştir. Mini araç kullanan bireylerin, üst sinıf otomobil kullanan bireylere göre alternatif yakıtlı araç kullanma olasılıklarının daha düşük olduğunu gösteren bu bulgu beklentiyle uyumlu elde edilmiş̧ir. Mini araç kullanan bireylerin daha düşük gelir grubunda yer almaları nedeniyle daha pahalı grupta yer alan alternatif yakıtlı araçları satın alma olasılıkları daha düşük olacaktır. Orta sınıf araç kullanan bireylerin elektrikli ve hibrit otomobil satın alma olasılıkları üst sınıf otomobili olan bireylere göre $\% 27$ oranında daha fazladır. SUV araç kullanan bireylerin elektrikli ve hibrit otomobil satın alma olasılıkları üst sınıf otomobili olan bireylere göre $\% 25$ oranında daha fazladır. Alternatif yakıtlı otomobillerin araç alış fiyatı $\% 25$ artar, yakıt maliyeti $\% 50$ azalırsa bireylerin elektrikli ve hibrit otomobil satın alma olasılıkları \%27 oranında artacaktır. Ancak, alternatif yakıt tüketen aracın satış fiyatının \%25 artması, CO2 emisyon salınımının \%50 azalması durumunda ise alternatif otomobil satın alma olasılığı $\% 3.4$ oranında azalacaktır. Alternatif yakıtlı otomobillerin araç alış fiyatı \%25 artar, yakıt maliyetinin ve CO2 emisyon salınımının $\% 50$ azalması durumunda ise alternatif otomobil satın alma olasılığı \%1.5 oranında artacaktır. Devletin alternatif yakıtlı araçlara teşvik vermesi, bireyin eğitim düzeyinin üniversite olması ise bireyin alternatif yakıtlı otomobil satın alma olasılığını \%3 oranında artıracaktır. Ancak hanedenki birey sayısnın artması alternatif yakıtlı otomobil satın alma olasılı̆̆ını $\% 3$ oranında azaltacaktır.

\section{Sonuç}

Dünya geneline bakıldığında küresel ısınmanın ve iklim değişiklinin arttığı görülmektedir. İklim değişikliği, çevreye duyarlılık ve enerji güvenliği ile ilgili endişeler çevre dostu teknolojilerin gelişmesine neden olmuş, daha yeşil ve sorunsuz birçevre için çevreyi olumsuz etkileyecek gazlardan uzak durmak için birçok alandaçalışmalar yapılmıştır. Bu nedenle içten yanmalı motorlu otomobillere kıyasla sera gazını, karbondioksit gazını ve emisyonlarını azaltan elektirik, hibrit ve pil gibi alternatif yakıtkullanan otomobillere ilgi artmış ve bu otomobiller piyasaya girmeye başlamıştır. Dünyada çevre sorunlarının gün geçtikçe artması, tüketicilerin ve üreticilerin çevreye olan duyarlılıkları elektrik, hibrit ve pil kullanan otomobil üretimininve tüketiminin artmasına yol açmıştır.

Türkiye'de otomobil kullanımı her geçen yıl artmaktadır. Artan nüfus da dikkate alındığında otomobil talebindeki artışı gelecek yıllarda da devam edeceği söylenebilir. Küresel ısınmanın etkisi dikkate alındığında Türkiye'de de alternatif yakıtlı otomobil 
kullanımınım zamanla artması beklenmektedir. Araştırma bulgularına bakıldığında, orta büyüklükte ve SUV tipi otomobile sahip olanların alternatif yakıtlı otomobil satın alma istekliliğinin yüksek olduğu belirlenmiştir. Alternatif yakıtlı araçların fiyatının \% 25 artması durumunda; yakıt maliyetinin \%50 azalması alternatif yakıtlı otomobil satın alınma istekliliğinde artışa neden olacağı, ancak yakıt maliyetinin azalmaması, ancak $\mathrm{CO}_{2}$ emisyonunda azalma olması durumunda alternatif yakıtlı araçların satın alma olasılı̆̆ının düşeceği belirlenmiştir. Ayrıca, devlet teşvikinin verilmesi, bireyin gelirinin yüksek olması ve üniversite öğrenim düzeyinde olması da alternatif yakıtlı otomobil satın alma olasılığını artırmaktadır.

Çalışmanın sonuçları göz önünde bulundurulduğunda, öncelikle eğitimle ve yasalarla bireylerde çevre bilincinin oluşturulması ve arttırılması gerekmektedir. Alternatif yakıtlı otomobil alımlarını negatif etkileyen faktörlerden biri yeterli alt yapının bulunmamasıdır. $\mathrm{Bu}$ durumla ilgili yatırımların artması ve girişimlerin desteklenmesi gerektiği söylenebilir. Genel olarak bireylerin yeterli teşvik ve vergi indirimleri sağlandığında alternatif yakıtlı otomobilleri satın alma eğilimlerinin artacağı gözlemlendiğinden bu konudaki teşvikler arttırılıp vergilerin düşürülmesi bu tip araçların daha yaygın kullanılmasının sağlanabileceği düşünülmektedir.

Alternatif otomobillerin kullanılmasıyla sıfır karbon salımı ile ulaşımın uygulanabilir olduğunu gösterebilmek için enerji tasarrufu sağlayan şarj edilebilir otomobillerin otoyollarda daha fazla görünür olması sağlanmalıdır. Bunun için gerekli altyapı çalışmalarının yapılması, şarj istasyonlaraltyapısının, yeni teknolojilerin (eMobility, IoT, Otonom sürüş) ve oluşacak yan sanayinin geliştirilmesine yönelik politikalara öncelik verilmelidir.

\section{Kaynakça}

Andriosopoulos, K.,Bigerna, S., Bollino, C. A., \& Micheli, S. (2018). The impact of age on Italian consumers' attitude toward alternative fuel vehicles. RenewableEnergy, 119, 299-308.

Aydemir, T. (2014) Elektrikli Araçların Çevresel Etkilerinin ve Yakıt Avantajlarının İncelenmesi. Gazi Üniversitesi, Yüksek Lisans Tezi. Ankara.

Blomquist, G. C. (2004). Self-protection and a verting behavior, values of statistical lives, and benefit cost analysis of environmental policy.Review of Economics of the Household,2(1), 89-110.

Dreyfus, M. K., ve Viscusi, W. K. (1995). Rates of time preference and consumer valuations of automobiles a fety and fuel efficiency. The Journal of Law and Economics,38(1), 79-10.

Gujarati, D. (2016). Örneklerle ekonometri.Nasip Bolatoğlu. (Çev.). Ankara: BB101 Yayınları.

Ito, N.,Takeuchi, K., ve Managi, S. (2013). Willingness-to-pay for infrastructure investments for alternative fuel vehicles. Transportation Research Part D: Transport and Environment, 18, 1-8.

Kerem, A. (2014). Elektrikli araç teknolojisinin gelişimi ve gelecek beklentileri, Mehmet Akif Ersoy Üniversitesi Fen Bilimleri Enstitüsü Dergisi 5 (1): 1-13

Musardo, C., Staccia, B, (2003).Energy Management Strategies for Hybrid Electric Vehicles, Master's Thesis, Politecnico Di Milan, Milano.

Özmen, M. T. (2009).Sera gazı - küresel 1sınma ve kyoto protokolü, IMO Dergisi, 45- 46.

TEHAD, (2019). http://tehad.org/. Erişim: 20.4.2019

Şengül Ü.,Eslemian S., Eren M. (2013).Türkiye'de istatistikî bölge birimleri sınıflamasına göre düzey 2 bölgelerinin ekonomik etkinliklerinin vza yöntemi ile belirlenmesi ve tobit model uygulaması. Yönetim Bilimleri Dergisi, 11(21), 78. 